\section{II. 我々はどこに向かっているのか}

温暖化問題を考えるにあたって，まず，我々がどこに 向かって進んでいるのかを概観しょう。さらには，どの ような温室効果ガスの排出シナリオがありうるのかをみ よう。第 1 図が示すように, 1950年の人口は 25 億人, 2008 年には66億人，2050年には 92 億人になろうとしている。 つまり，世界の人口は，2008年から 2050 年にかけて 1.4 倍になると予測されている。一方, 世界生産 (GWP : Gross World Product)は，1950年には 8 兆ドル，それが2008 年には8.4倍の67兆ドルである。これが2050年には2008 年の6.3倍の420兆ドルになろうとしている (Jeffrey D. Sachs $(2008))$ 。

それでは世界全体における大気中への炭素排出はどう か(Marland et al.)。1950年は16億トン，2004年は1950 年の 5 倍の79億トンである。GWP あたりの排出量は, 1950年で16/8 $=2$ (億トン/兆ドル), 2004年から 2008 年 あたりのそれは $79 / 67=1.2$ (億トン/兆ドル)であり，か なり改善していることがわかる。GWP 1 単位あたりの 炭素排出がほぼ線形で改善するとし, 2050年のそれを0.4

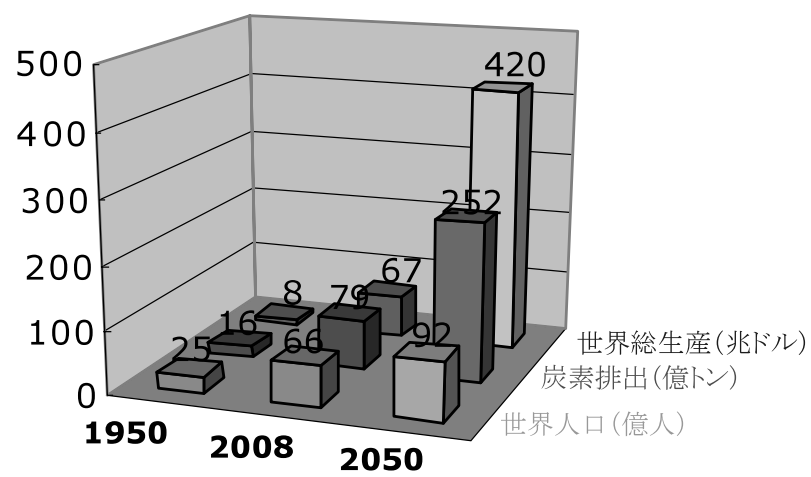

第 1 図 世界人口・炭素排出・世界総生産(炭素排出のデー 夕は2004年)

Toward Designing Institutions Coping with Climate Change ; A View of an Economist : Tatsuyoshi SAIJO.

(2008年 9 月 2 日 受理)
だとしよう。そうすると 2050 年の炭素排出は $420 \times 0.4$ $=168$ 億卜ン，もしそれが少し鈍り0.6だとするなら 252 億トンである。なお, 国際エネルギー機関の現状維持 (Business As Usual:BAU) 予測は2050年で169億トンで ある(IEA, Energy Technology Perspective 2008)。

2008年の G 8 洞爺湖サミットなどで提案されている 2050年半減の意味を考えてみよう。どの年における排出 量の半減なのかが定かではないのだが，1990年の炭素排 出量 (58億トン)ではなく2004年の79億トンの半減という 緩い目標をとりあえず採用しよう。2004〜 8 年あたりの 指標として，1 人あたり 1.2 トンの排出をとろう。もし 2050 年の BAU 排出量が168億トンなら 1 人あたりの排 出は 1.8 トン, 252億トンならそれは 2.7 トンである。 2050 年に半減というのを 1 人あたり 0.6 トンと考えるとし， BAU 排出が 168 億卜ンなら $1 / 3 ， 252$ 億卜ンなら $1 / 5$ に落 とさねばならないのである。これは世界の平均であっ て，先進国の排出はさらに抑えられたものとなるに違い ない。なお，日本の 2006 年における 1 人あたりの炭素排 出量は 3.7 トンであり，2050年に 1 人あたり 0.6 トンにす るためには，1/6以下に落とさねばならない。

今度は，2007年に公表された気候変動に関する政府間 パネル (IPCC)の第 4 次報告書における 6 つの気候安定 化シナリオ(カテゴリー)のうち，いくつかを眺めてみよ う (IPCC AR 4)。第 2 図で示すように, 2100年以降, 産業革命以来の気温上昇が $2 \sim 2.4^{\circ} \mathrm{C}$ の幅で 2100 年以降

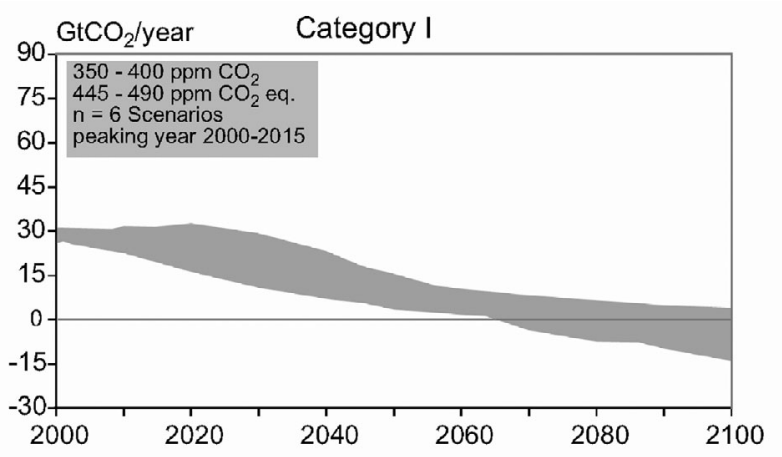

第 2 図 IPCC 気候安定化排出シナリオ：カテゴリ 1 (2.0 $\left.2.4^{\circ} \mathrm{C}\right)$ 
において安定化するシナリオがカテゴリー 1 である。温 室効果ガスの総排出のピークは2000年から15年の間で, 2050年の2000年比における総排出は15\%から50\%であ る。このシナリオは $\mathrm{EU}$ 提案や洞爺湖サミット提案に相 当する。なお, 温度変化は全球の平均であって, 極地方 では平均気温上昇の約 3 倍の温度変化が起こるといわれ ている。

第 3 図はカテゴリー 3 のグラフである。2.8〜 $3.2^{\circ} \mathrm{C}$ 程 度の温度上昇で安定化するシナリオであるが，この場合 だと，2050年の総排出は2000年比で70\%から105\%であ る。なお, 斜線部分は二酸化炭素濃度を $450 \mathrm{ppm}$ に安定 化させるための IPCC 第 3 次報告書におけるシナリオで ある。

以上みたように，「どこに向かっているのか」と「求め られているものは何か」のギャップはあまりにも大き い。この意味で, 温暖化問題は人類始まって以来の難問 といえよう。つまり，小手先や奇策では解きようがない のである。正攻法でやるしかないといってよい。低炭素 社会に向けて, 排出パスを策定し, 温室効果ガス排出を 抑制する技術を開発し，それを世界に普及せねばならな い。同時に目標を達成する社会制度のデザインをせねば ならないのである。とはいえ, 正攻法の中身自体に関し 合意を築くのは容易ではない。次章では, 温暖化問題の 公共性に焦点を当て, 社会科学的な見方を試みてみよ う。

\section{. II. . 温暖化問題における公共性}

温暖化問題においては，現世代が将来世代の地球環境 を変えうるという時空を超えた公共性の問題があること をみよゔ。

経済学では,「公共財」は自発的には供給されないとい う命題がある。公共財とは, 誰でも使えるないしは使わ ざるを得ない財・物質のことである。たとえば，町内会 で作った公園は誰でも遊べる。また，污染された空気は 誰もが使わざるを得ない。大気の温度もしかりである。

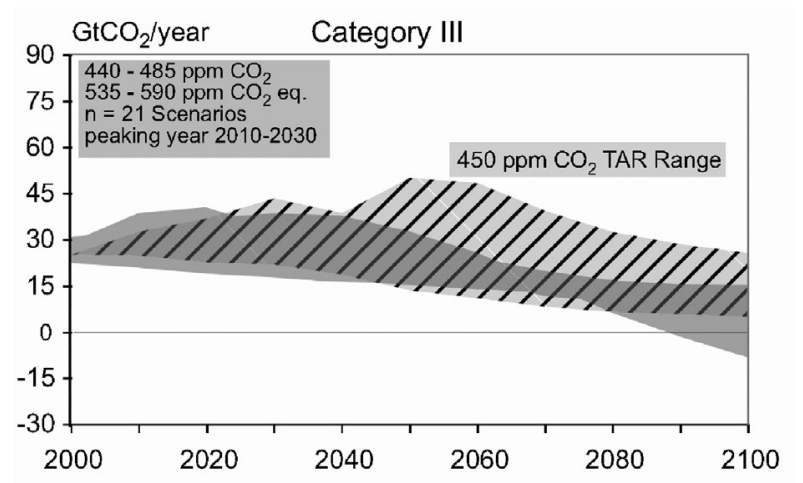

第 3 図 IPCC 気候安定化排出シナリオ : カテゴリー $3(2.8$ $\sim 3.2^{\circ} \mathrm{C}$ )
ある町内会の真ん中に公園を作る計画があるとしよう。 この町内会には北地区と南地区があって，おのおの自発 的にお金を出し合って公園を作るとしょう。話をさらに 単純にするために，おのおのの地区は10単位の資金を出 すか, 出さないかの判断(ないしは戦略的意思決定)をせ ねばならないとしよう。

この様子を示したのが，第 4 図である。各セルの左下 は南地区，右上は北地区の住民の利得とする。10単位の お金を出さないなら，お金が手元に残るので利得を10と している。出したお金の総額に 8 割かけた分だけ，片方 の地域のみではなく, 両地域の住民が便益を受けるとし よう。たとえば，両地域とも10単位の資金を出すと，総 額は20単位。この 8 割は16単位なので, 右下のセルは両 地域とも16単位の利得となっている。片方のみでなく, 両地域に便益がいくところが公共財たるゆえんである。 仮に南地区のみ 10 単位の資金を供給するなら, 公園の設 備が十分ではないので，8 単位分の便益を両地域の住民 が受けるとしょう。つまり, 左下のセルの南地区の利得 は 8 , 北地区のそれは資金を供給していないので18とな る。

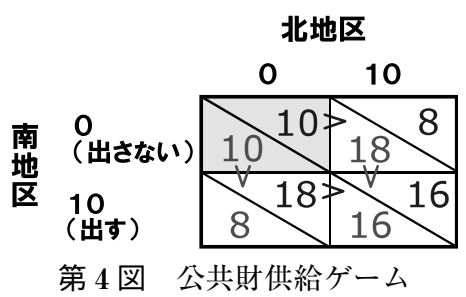

この状況で南地区はどちらの戦略をとるのだろうか。 相手が資金を出さない場合, 出す ( 8 単位の利得)よりも 出さない(10単位の利得) 方が得である。相手が 10 単位出 す場合もやはり出さないほうがベターである。つまり, 南地区は出さないを選択するであろう。同様に北地区も 「出さない」を選択するに違いない。そうなら，両地区で お互いに資金を提供して公園を作るなら16単位の利益を 得られるのに，公園を作らずに手元に10単位の資金を残 すのみになる。地域全体で考えるなら，公園があったほ うがよいのにも関わらず公園は作られないことになる。

この問題では，両地域の住民が集会を開いてよく話し 合うことによって互いに資金を出し合い，公共財である 公園ができるかもしれない。ところが，地球温暖化の問 題は話し合うことのできない将来世代，ないしは現時点 で戦略を選択のできない将来世代とのゲームである。こ のことを仮想的な数值で示したのが第 5 図である。第 4 図の南地区を現世代，北地区を将来世代としょう。現世 代の人々が意思決定をするときには，将来世代は生まれ てすらいないので，将来世代が出そうが出すまいが，現 世代の利得には変化がない。つまり, 現世代の利得は将 来世代の利得とは無関係である(将来世代の選択にかか わらず現世代が「出す」場合の利得は 10 ,「出さない」場合 


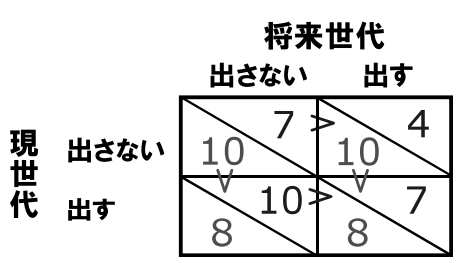

第 5 図 現世代と将来世代の公共財供給ゲーム

の利得は 8$)$ 。10のほうが 8 よも大きいので，当然， 現世代は温暖化対策のために資金を投入しないのがべス トとなる。

将来世代の選択は，現世代の選択に依存する。もし現 世代が「出さない」という選択をするなら, 将来世代は「出 さない」場合の利得 7 と「出す」場合の利得 4 の選択をせ ねばならない。つまり，利得表の上の部分のみである。 現世代が「出す」という選択とするなら, 将来世代は「出 さない」の場合の利得 10 と「出す」場合の利得 7 の間の選 択となる。将来世代も現世代と同様の問題，つまり将来 世代の次の世代とのゲームに直面することになる。

さらに第 4 図と異なるのは，現世代が「出す」という選 択をしても，現世代は「出す」ことの利益を享受できな い。損をするのみである。これに加えて目に見えない相 手との交渉，協力は容易ではない。大げさにいえば，現 世代は内なる「人類」との対話を通じて, 現世代と将来世 代の負担の衡平性を含む現世代の政策をデザインせねば ならないのである。

我々の内なる「人類」との対話の一表現として, 現世代 が自己の利得と将来世代の利得の合計額に注意を払って いるとしょう。第 1 表は, 現世代と将来世代の戦略と利 得を示している。将来世代が「出す」場合, 現世代が「出 す」場合の利得は 15 , 「出さない」場合の利得は 14 となり, 将来世代が「出す」限りにおいて, 現世代も「出す」のがよ い。一方，将来世代が「出さない」場合，現世代が「出す」 場合の利得は 18 , 「出さない」場合の利得は 17 となり, 将 来世代が「出さない」場合, 現世代は「出す」のがよい。つ まり, 現世代が将来世代の利得を現世代の利得と同じ重 さで考えるのなら，「出す」のがよいことになる。

しかし, 現世代が将来世代の利得を半分に割り引いて 考えるとしょう。 5 列目の数值は 4 列目の数值の半分で ある。上記と同じように考えると，将来世代が出そうが 出すまいが，現世代は「出さない」ことがよいことにな る。以上は極端な例ではあるが, 将来世代の利得をどの
程度割り引くかによって現世代の戦略が正反対になるこ とすらあり得る。温暖化対策に関わる様々な提案ないし は考え方の背後に将来世代の利得をどの程度割り引くの かが潜んでいるのである。

現世代と将来世代の負担の衡平性はさらに複雑であ る。これまでの例では「出す」「出さない」でどの程度出す のかを明示的に出していない。出費額の総額なのか， 1 人あたりの出費額なのか，それとも将来世代が得るであ ろう利得に比してなのか，などなど様々な衡平性の指標 が考えられる。さらに問題を複雑にしているのは，将来 世代の利得の不確実性である。この不確実性は気候变動 にかかわる物理的な不確実性と共に社会制度のデザイン に付随する人間行動そのものの不確実性の両方を含むこ とになる。

さらに温暖化問題は，現世代内部でも温暖化対策のコ ストをどのように負担するのかという先進国と途上国の 問題, さらには先進国内, 途上国内の問題を含んでいる。 このような構造を背景に, 気候変動枠組み条約およびそ のもとで策定された京都議定書が出現したのである。つ まり,条約を策定した人々は, 第 5 図のような構造を持っ た問題に対処するためには，現世代内の主体が「自主的」 に行動するのみでは解決できないことを十分に理解して いたのであろう。

\section{III.. 温暖化問題における市場の意味}

経済学のテキストには，外部性や不確実性がある場合 には市場は失敗する，と書かれている。外部性とは，あ る主体の活動が他の主体に直接影響を与える場合を指 す。現世代の温室効果ガスの排出が将来世代の気候に影 響を与えるのである。前章でみたように，温暖化は不確 実性も伴う。このため, なんらかの制度的な仕組みが必 要とならざるを得ない。つまり，原理的に，現世代の「自 主的」な努力のみでは問題の解決はできないのである。 このため, 経済的手法として, 炭素税や排出権取引など が考えられている。本章では，炭素排出に価格をつける ことの意味を考えてみよう。

政府による暗黙のプレッシャーであれ，自主的であ れ，2つの主体がおのおの 1 単位の温室効果ガスを削減 せねばならない状況を考えてみよう。主体 1 の削減コス トは10ドル, 主体 2 の削減コストは200ドルだとしよう。

第 1 表＼cjkstart将来世代の利得も考慮に入れた利得表

\begin{tabular}{|c|c|c|c|c|c|c|}
\hline $\begin{array}{c}\text { 現世代の } \\
\text { 戦略 }\end{array}$ & $\begin{array}{c}\text { 将来世代 } \\
\text { の戦略 }\end{array}$ & $\begin{array}{c}\text { 現世代の } \\
\text { 利得 }\end{array}$ & $\begin{array}{c}\text { 将来世代 } \\
\text { の利得 }\end{array}$ & $\begin{array}{l}(1 / 2) \times \text { 将来 } \\
\text { 世代の利得 }\end{array}$ & 現 + 将 & 現 $+(1 / 2) \times$ 将 \\
\hline 出す & 出す & 8 & 7 & 3.5 & 15 & 11.5 \\
\hline 出さない & 出す & 10 & 4 & 2 & 14 & 12 \\
\hline 出す & 出さない & 8 & 10 & 5 & 18 & 13 \\
\hline 出さない & 出さない & 10 & 7 & 3.5 & 17 & 13.5 \\
\hline
\end{tabular}


市場は用いないものの, 主体 1 の場合, 削減量 1 単位あ たり10ドルという「影の価格」, 主体 2 には200ドルの「影 の価格」がかかるのだから，炭素排出に価格付けをする ことに成功している，とする見方がある。

残念ながら，この「価格」は「市場」による価格ではな い。両者が異なった価格に直面しているからである。上 例の場合, 仮にキャップ・アンド・トレイド型の排出権 取引(各主体にキャップと呼ばれる排出上限を課し，そ れを超えない主体は差分を排出権として販売, 超えた主 体はその増分を超えない主体から排出権として購入する 取引)のキャップからの削減コストだとし, 排出権価格 が20ドルだとしょう。そうすると，主体 1 は自己で削減 をせずに, 20 ドルを出して排出権を 1 単位購入し, 主体 2 は 2 単位削減をし， 1 単位は自己の目標達成に，もう 1 単位は主体 1 に販売するであろう。

この両者の違いはどこにあるのだろうか。「影の価格」 の場合, 両者での削減コストは210ドル, 一方, 排出権 取引の場合, 主体 2 の 2 単位目の削減コストも 10 ドルと するなら，それは 20 ドルとなる。つまり，市場を用いる ことによって, 190 ドル節約できることになるのである。 これこそが市場の持つ効率性である。炭素税は炭素排出 に税率という同じ価格をつけることになるので, 排出権 取引と同様の節約ができることになる。

二酸化炭素トンあたりの価格が数百ドルになると, 温 暖化対策への費用が巨額になり，そのような負担を現世 代がするのはほぼ不可能という議論に出くわすことがあ る。おのおのの企業の費用を積み上げる手法である。こ の手法は, われわれの直感に訴えはするものの, 真の費 用ではない。というのは誰かの支出はほかの誰かの収入 になる点を考慮に入れていないからである。温室効果ガ スを削減するために電源を太陽光パネルに変えたとしよ う。その事業主にとっては費用となっても，太陽光パネ ルの製造業者，運搬者，設置者などにその資金が流れる のである。つまり, 高炭素社会から低炭素社会への変革 が起こるといってよい。このような変革の中で, 従来型 の炭素を多く排出する産業の事業主体も自ら炭素を排出 しない体質に変革せねばならない。突き放した言い方か もしれないが，炭素を多く排出する主体は市場から退場 せざるを得ないのである。

それでは, 何が真の費用なのだろうか。温室効果ガス の排出に制限がかからない時の GWP(国単位なら GDP) と制限がかかる時の GWP (GDP)の差が真の費用とな る。様々なモデルによる数值計算があるが，2006年の国 立環境研究所のモデルによると, 米国が参加しないこと を前提とする場合, わが国が京都議定書の目標を達成す る際に失う GDP は $0.07 \%$ か $0.19 \%$ 程度である ${ }^{2)}$ 。日 本経済への影響は軽微といってよいであろう。なお，こ こで算出されている二酸化炭素トンあたりの価格は 7 ド ルである。
しかしながら，近年の EUにおける排出権取引価格が 二酸化炭素トンあたり25ユーロ前後で推移しているの で, もっと排出権価格が高いとどのような影響が日本経 済に出るのか疑問に思うのは自然である。これに答える 現象がこの 1 年で観察された。原油の価格がこの 1 年で 倍前後に上昇したのである。それに伴い, 国内のガソリ ンの価格・消費量共に大幅に変化した。この間の事情を 整理しよう。2007年 6 月のガソリン 1 リットルあたりの 価格は139円，2008年 6 月のそれは172円。33円の上昇 である。この間，ガソリン消費量は $6.1 \%$ 減少した。炭 素排出からみた 33 円の意味をみよう。ガソリン 1 リット ルあたりの炭素含有量は0.000649トン。炭素トン価格 $\times$ $0.000649=33$ 円だから，この間の価格上昇分の炭素卜 ン当たりの価格は 5 万円強(炭素の分子量 12 と二酸化炭 素の分子量44を考慮に入れると二酸化炭素トン当たりの 価格は13,867円(約126ドル))。なお，ガソリンの価格は 2007年 7 月が141円，2008年同月が182円なので，41円 の上昇である。これは二酸化炭素トンあたり17,650円(約 160 ドル)である。直近の統計によると 2008 年 $4 \sim 6$ 月期 の国内総生産 (GDP) は年率換算で2.4\%減となっている。

これらのデー夕をみるとわかるように，価格の変化に よって消費量が変動するのである。炭素税や排出権取引 などで炭素排出に価格をつけることを拒む人々は，価格 変化による温室効果ガス排出量の変動はあまりないとい う信念を根拠にそれらに反対しているようだが，彼らの 信念に疑念がわいてしまう。次に, 価格変化の幅である。 二酸化炭素トンあたりの変動でみると100〜200ドルの間 の変化が短期間に起こった，ということである。このよ うな大幅な変動に日本経済は耐えられない訳ではないの である。GDP の減少幅の $2.4 \%$ のすべてが原油価格上昇 によるものではない。なお，資金が海外に流出する場合 と炭素税のように税収を国内還元する場合では, 後者の GDP 減少幅が小さくなるに違いない。

市場を用いる提案として，世界市民の扔の扔のに同量 の排出権を与え, 後は排出権取引市場に任せるという手 法がある。仮に現状から世界全体で温室効果ガスを $10 \%$ 削減するという目標を立て，1 人あたり同量の排出権を 各国に振り分け，排出権取引市場を用いるとしょう。そ の結果を示したのが第 2 表である (Hamasaki and Saijo (2008))。なお，このときの二酸化炭素トンあたりの価 格は7.5ドルである。まずどの国・地域も GDP の減少 は軽微である。米国, EUの場合は, 減少ではなく,わ ずかではあるが増加になっている。比較的減少幅が大き いのが中国，カナダである。一方，大幅に削減するのが 中国と他のアジア地域に含まれるインドである。1 1 人あ たり同量の排出権保有から出発しても, 結果としての 1 人あたりの排出量の差が開くことになる。このため，多 くの削減をする国々になんらかの手当をする必要があ る。とはいえ，世界経済に大きなダメージを与えること 
第 2 表 $10 \%$ 削減に対応する排出量と GDP の変化

\begin{tabular}{lcc}
\hline \multicolumn{1}{c}{ 国・地域 } & $\begin{array}{c}\text { BAU }(100 \%) \text { と比較 } \\
\text { した排出量 }(\%)\end{array}$ & $\begin{array}{c}\text { GDP の減少 } \\
(\%)\end{array}$ \\
\hline 豪州+NZ & 91.7 & -0.10 \\
中国 & 68.0 & -0.48 \\
日本 & 96.8 & -0.01 \\
韓国+台湾 & 94.5 & -0.06 \\
タイ & 94.2 & -0.04 \\
他のアジア諸国 & 88.7 & -0.09 \\
米国 & 91.7 & 0.03 \\
カナダ & 98.2 & -0.31 \\
EU & 97.3 & 0.05 \\
旧ソ連 & 92.2 & -0.38 \\
その他の国々 & 93.7 & -0.08 \\
\hline
\end{tabular}

なく, 現時点でもかなりの削減が可能であるというのが メッセージであり，2050年半減目標達成の一つの階梯に なるのではなかろうか。

\section{$\mathrm{N}$. 迷走する日本の提案}

京都議定書第一約束期間以降の日本政府の新たな戦略 が「セクター別アプローチ」である。世界の同じ産業に属 する企業がその産業におけるべスト・テクロノジーを シェアする手法である。この意味で, 技術の普及の仕組 みであり，技術普及それ自体は非常に重要である。たた， 技術普及の仕組みそのものが世界の温室効果ガス削減の 枠組みになるはずはない。つまり, 七クター別アプロー チは目標を策定するという戦略ではなく, 目標が決まっ てからの戦術といってよい。もちろん, 目標がなくても この技術移転の手法を使うことはできる。

世界の目標を決めることなく，七クター別アプローチ のみが生き残ることを期待している人々もいるようだ が, こうなってしまうと, 政府の試算とは異なって温室 効果ガス排出削減は望めないのではなかろうか。途上国 や中進国に日本の技術が移転されるとしよう。そうする と, 他の生産要素，たとえば労働の賃金が安いので，同 じセクターに属する先進国の企業は遅かれ早かれ規模の 縮小，撤退を余儀なくされるであろう。たとえそうなっ ても世界の温室効果ガスの削減につながればよいと，わ が国の産業界の首脳は考えているのだろうか。しかし， 途上国のそのセクターの生産物 1 単位当たりの温室効果 ガスの排出は減るものの, 総量として減るのだろうか。 数量が増えると総量も増える可能性がある。さらには, そのセクターを中心に経済が活性化され, その周辺の産 業や民生・運輸の排出量が増えてしまう可能性もある。

ひとつの可能性として, 産業界の温室効果ガスの排出 は抑えられるものの, 民生・運輸で大幅に増えてしま う，というわが国が経験している，いわば「日本問題」を 途上国・中進国に輸出してしまうことになる。このよう
なロジックが杞憂であることを祈るばかりであるが，応 用一般均衡モデルによる試算は以上のことをサポートし ているようである。

もちろん，日本政府はセクター別アプローチを元に国 別総量目標を策定する，と提案している。日本の削減ポ テンシャルは小さく，中国などのそれは大きいことが出 発点である。しかし，どのような原理・原則で各国の目 標を決めるのかは定かではない。単純かつ明快な原理 · 原則でなければ，他国はそれに追随するはずがない。

セクター別アプローチには原理的な疑念がある。20世 紀前半の経済計画論争から始まり旧ソ連邦崩壊に至る過 程における数量指令型システムの劣位性である ${ }^{3)}$ 。セク ター別アプローチでは，「価格」変数を用いることなく, 限界削減費用が均等化可能 (最もコスト効率的に目標達 成可能)であることを前提にしている。この意味で, 概 念的には数量指令型の一類型である。残念ながら, 少な くともこの百年，「価格」を明示的に用いないシステムが 機能した試しがないのである。

\section{一参考文献一}

H. Hamasaki, T. Saijo, "Designing Post-Kyoto Institutions: From the Reduction Rate to the Emissions Amount," mimeo., 2008.

IEA, Energy Technology Perspective 2008, http://www. iea.org/Textbase/techno/etp/index.asp

IPCC Fourth Assessment Report (AR 4 ), “Climate Change 2007", http : //www.ipcc.ch/

G. Marland, T.A. Boden, R.J. Andres, “Global, Regional, and National Fossil Fuel $\mathrm{CO}_{2}$ Emissions," http : //cdiac.ornl. gov/trends/emis/em_cont.htm

J. D. Sachs, Common Wealth: Economics for a Crowded Planet, Penguin Press, (2008).

鈴村興太郎, 経済計画理論, 筑摩書房, (1982).

鈴村興太郎，蓼沼宏一，“地球温暖化の厚生経済学”，世代間 衡平性の論理と倫理, 鈴村興太郎編, 東洋経済新報社, (2006), 所収.

1）鈴村・蓼沼 (2006)を参照されたい。

2) http : //www.env.go.jp/council/06 earth/y 060-kyo/ mat 01.pdf を参照されたい。

3）経済計画論争については, 鈴村 (1982)を参照されたい。

著者紹介

西條辰義(さいじょう・たつよし)

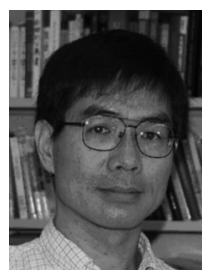

大阪大学社会経済研究所

(専門分野) 制度設計，実験社会科学 